Academic City University College - Accra Ghana

Society for Multidisciplinary \& Advanced Research Techniques (SMART) Africa

Tony Blair Institute for Global Change

FAIR Forward - Artificial Intelligence for All - Deutsche Gesellschaft für Internationale Zusammenarbeit (GIZ) GmbH

Accra Bespoke Multidisciplinary Innovations Conference (ABMIC)

\title{
Editorial and the Moulding of Opinion: A Survey of Newspaper Readers in Tertiary Institutions in Imo State, Nigeria
}

Obayi, Paul Martin, Ph.D

Department of Mass Communication, Godfrey Okoye University, Enugu, Enugu State

E-mail: frobayi@gmail.com

Phone Number:+2348062384720

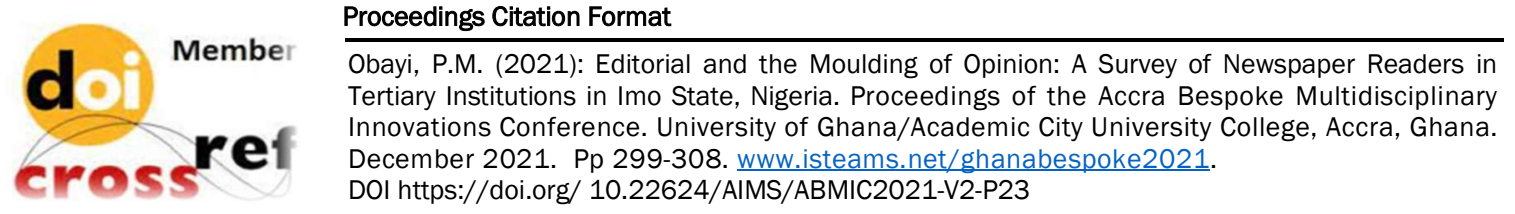




\title{
Editorial and the Moulding of Opinion: A Survey of Newspaper Readers in Tertiary Institutions in Imo State, Nigeria
}

\author{
Obayi, Paul Martin (PhD)
}

\begin{abstract}
The power of editorials in moulding public opinion cannot be over-emphasized. Editorials have the potentials to change the attitudes of the public towards government and governmental policies. Therefore, employing newspaper texts like editorials will help offer background information and interpretation necessary to shape public opinion and attitudes. Readers turn to editorials for opinion, discussion, and interpretation covering those matters which are for the day, attracting attention. This study is anchored on the framing theory which was put forth by Erving Goffman in 1974. The researcher adopted the survey research design. The population of this study comprises of newspaper readers in tertiary institutions in Imo State. The tertiary institutions in Imo State that this study focused on include; Imo State University, Owerri, Federal University of Technology, Owerri, Federal Polytechnic, Nekede, Alvan Ikoku Federal Collage of Education, Owerri. The population of newspaper readers are not statistically known in these institutions. This means that the sample size of this study is 384. In order to determine the number of questionnaire to be administered to each of the selected tertiary institutions in Imo state, the non-proportionate and purposive sampling techniques were used. The questionnaire was the research instrument used for the data collection. The data collected from the respondents was analysed and interpreted by using the simple percentages tables and frequency analysis. Analysis of data collected from the field revealed that 162 respondents representing $42.6 \%$ said that their readership of editorials in newspapers was to a very large extent. Further analysis also revealed that at an average mean of 2.9 , newspaper readers in tertiary institutions were of the view that they were being influenced by the content of editorials that they read from newspapers. Communicating result from data revealed that at an average mean of 2.7, newspaper readers in tertiary institutions in Imo State were of the view that the persuasive nature of editorials and the level of education of the person reading the editorials were the major factors responsible for the influence that editorial has in moulding peoples' opinions. The researcher recommended that newspaper readers should continue to read editorials in order to form more informed opinions on topical issues.
\end{abstract}

Keywords: Editorial, Moulding, Opinion, Survey, Newspaper, Readers and Tertiary Institutions

\section{INTRODUCTION}

In recent times, the power of the media to mould public opinion has increased. More people are turning to the media to have an informal opinion on topical issues in the society. Mughal (2014) noted that the correlation, interpretation and analytical prowess of the media has increased with the development in society. The newspaper is one aspect the media that has taken this function of the media to another level. This is more so especially when looking at the thematic content of the newspaper such as editorial. 
Editorial influences the social values, perception, aspirations, opinions and ideas of readers through analytical and interpretative presentation of facts. Editorial also engage in political analysis and holding the government accountable to the society by taking a position based on facts (Eilders, 2000).

Newspapers use the editorial to explain the meaning of the news and thus, influence public opinion; interprets, examines, contextualizes and judges key events, and on the whole, influence voting behaviour, modify government decisions, and strengthen (or discredit) political institutions. In short, editorials affect public opinion both as agenda-setting and in the way they influence social debate, decision making and other forms of social and political action (D'Angelo \& Shaw, 2018).

Through interpretative, evaluative and potentially persuasive content, the editorial can provide orientation to the voters on election matters by the judgements made regarding policy, political actors and political decisions (Eilders, 2000). This helps the publications typical reader to be informed, educated, persuaded and influenced. Principally, editorials educate, provoke debate and offer enlightened judgments to their readers.

Notwithstanding the ability of editorial to provide the factual analysis and interpretation that has the propensity to alter reader's opinion, many people seem not to appreciate editorial contents due to the lengths and subjective analysis. Baker and Macdonald (1961) cited in Sage Journal (2022) observed that readers are losing interest in editorial because of the length and lack of pictures to back their line of thoughts. The chances of gaining the benefit of editorial is slim when readers refuse to read the content.

Today, technological development has aided most newspaper outfits to improve on the dynamics of editorial writing. As media houses launch their online presence, editorials have also gone online and are accessed by readers through the aid of the internet. Orosa, Garcia, and Santorum (2013) maintained that the editorials also appear in the homepage of the online newspapers, and the online edition offers readers a couple of hyperlinks to documents that expand the editorial information, read them on various social media platforms and share the editorial as well. Whether editorials are online or hard copy, it does not limit the power of the contents to influence public opinion.

This study therefore, sought to examine the influence of editorials in moulding public opinions among newspaper readers in tertiary institutions in Imo State.

\subsection{Statement of the Problem}

The power of editorials in moulding public opinion cannot be over-emphasized. Editorials have the potentials to change the attitudes of the public towards government and government policies. Therefore, employing newspaper texts like editorials will help offer background information and interpretation necessary to shape public opinion and attitudes (Ciboh, 2014). Despite the potential for editorial to mould public opinions, majority of the populace seem not to have similar thought on critical issues affecting the country. This is evident in the dissenting voices noticed in the country on issues such as IPOB agitations, the covid-19 pandemic, banditry, ASUU strike issue etc. Based on these likely dissenting voices, one is compelled to ask; could it be that editorials do not influence public opinions anymore? This study therefore, sought to examine the influence of editorials in moulding public opinions among newspaper readers in tertiary institutions in Imo State. 


\subsection{Objectives of the Study}

The main objective of this study is to examine the influence of editorials in moulding public opinions among newspaper readers in tertiary institutions in Imo State. The specific objectives include to:

1. Examine the extent to which editorials are read by newspaper readers in tertiary institutions in Imo State.

2. Ascertain the influence of editorials in moulding the opinions of newspaper readers in tertiary institutions in Imo State.

3. Identify the factors that encourage the influence editorial has in moulding the opinions of newspaper readers in tertiary institutions in Imo State.

\subsection{Research Questions}

The following research questions have been designed to guide the study:

1. To what extent are editorials read by newspaper readers in tertiary institutions in Imo State?

2. What is the influence of editorials in moulding the opinions of newspaper readers in tertiary institutions in Imo State?

3. What are the factors that encourage the influence editorial has in moulding the opinions of newspaper readers in tertiary institutions in Imo State?

\section{EDITORIAL AS RHETORICS AND OPINION FORMATION}

In 2005, Duyile noted that editorial is the opinion of the newspaper written for the comprehension of readers in order for them to take an informed decision on the issue being discussed. He further noted that editorial is an explanatory write-up in support of a policy, action or idea based on the opinion of the newspaper. Basically, it is a persuasive essay that offers a solution to a problem. Okoro and Agbo (2003) considered editorial as 'a critical evaluation, interpretation and presentation of significant, contemporary events in such a way as to inform, educate, entertain and influence the reader'.

Hoffman (2007) averred that editorial is a system of opinion from the editor of a newspaper. It is important to note that this opinion is backed up by facts and strong argument. It is usually published in a distinct page called editorial page.

Meltzer (2007, p.83) "describes this page as a section of the newspaper where the masthead and staff listing of the newspaper can be found, including the owner's name or company's name, one to four editorials, syndicated and local guest writers, political cartoons and letters to the editor. It is only here that openly acknowledged opinion as opposed to traditional 'neutral' reporting is published." A good editorial uses different strategies to actualize its argument. However, it is important to state that editorials are highly persuasive rather than flattering. This is where the idea of rhetoric comes in. According to Richardson (2007), rhetorics are developed by using persuasive facts to present a given case or ideology in such a way that is convincing enough for the audience to take a given action. It is the proper, interpretation, construction and use of supporting materials to back assertions and gain audience acceptance.

From the aforesaid, it is clear that the writers of editorials are at home with the concept of rhetorics as a persuasive way to win an argument. When the editorials are written using rhetorics as foundation, then its power to influence and mould opinion among readers is increased. 


\subsection{Theoretical Framework}

This study is anchored on the framing theory which was put forth by Erving Goffman in 1974. The theory opined that the media has the power to put images in people's mind through the choice of words and language used in presenting an argument. Eaton (2020) defines framing as "the way a message's delivery affects the interpreter's understanding". According to Ciboh (2010, p. 69), 'the concept of framing expands the agenda setting research tradition by focusing on the essence of the issues at hand rather than on particular issue'. This form of agenda setting not only tells what to think about an issue, but also how to think about that issue.

The relevance of this theory to the study is that it explains how the media helps in moulding public opinion by deliberately picking an angle of analysis, words, phrases, sentences and facts to present. When people read the argument presented in editorial as it has been formed by the newspaper, they have no choice than to form that opinion.

\section{METHODOLOGY}

The researcher adopted the survey research design. The population of this study comprises of newspaper readers in tertiary institutions in Imo State. The tertiary institutions in Imo State that this study focused on include; Imo State University, Owerri, Federal University of Technology, Owerri, Federal Polytechnic, Nekede, Alvan Ikoku Federal Collage of Education, Owerri. The population of newspaper readers are not statistically known in these institutions. However, considering that staff strength and population of students in these institutions, one can estimate the population to be above 100,000 persons. Due to the fact that the researcher is using an estimated value in population, the $Z$ score formula was used to determine the sample size for the study. The formula is $n=Z 2(P)(1-P) / C 2$. This means that the sample size of this study is 384.

In order to determine the number of questionnaire to be administered to each of the selected tertiary institutions in Imo state, the non-proportionate and purposive sampling techniques were used. The non-proportionate sampling technique requires that the sample size be divided among the selected institutions. In this cases, 384 is divided by 4 to get 96 . Imo State University, Owerri; Federal University of Technology, Owerri; Federal Polytechnic, Nekede and Alvan Ikoku Federal Collage of Education, Owerri having 96 each. The purposive sampling was then used to select newspaper readers from within the institutions.

The questionnaire was the research instrument used for the data collection. This research work is reliable because 10 copies of the instrument were administered as a pilot study to see the level of consistence in responses of the respondents. Their responses were all consistent and as such the instrument was deem to be reliable. The data collected from the respondents was analysed and interpreted by using the simple percentages tables and frequency analysis. Simple tables, frequencies and percentage were adopted in the presentation and analysis of the data generated for the study. 


\section{PRESENTATION AND ANALYSIS OF DATA}

This section contains the analysis of data gotten from the field. The researcher distributed 384 copies of the questionnaire but was only able to retrieve 380 copies which were valid and appropriate for analysis.

Research Question One: To what extent are editorials read by newspaper readers in tertiary institutions in Imo State?

Table 1: Respondents extent of readership of editorials

\begin{tabular}{|l|l|l|}
\hline Option & Frequency & Percent \\
\hline Very large extent & 162 & 42.6 \\
\hline Large extent & 138 & 36.3 \\
\hline Moderate & 50 & 13.1 \\
\hline Low extent & 20 & 5.2 \\
\hline Very low extent & 10 & 2.6 \\
\hline Total & 380 & 100 \\
\hline
\end{tabular}

Source: Field survey, 2021

Table 1 shows that 162 respondents representing $42.6 \%$ said that their readership of editorials in newspapers was to a very large extent. If this is added to the $36.3 \%$ of the people that said their readership of editorials was to a large extent, it will show that the the extent of readership of editorial was to a large extent as $78.9 \%$ of the readers were of that view.

Research Question Two: What is the influence of editorials in moulding the opinions of newspaper readers in tertiary institutions in Imo State?

Table 2: Respondents' view on the Influence of editorials in moulding their opinions $(\mathrm{N}=380)$

\begin{tabular}{|l|l|l|l|l|l|l|}
\hline Option & SA & A & D & SD & Mean & Decision \\
\hline $\begin{array}{l}\text { Editorial provides in-depth analysis on } \\
\text { a given topic. }\end{array}$ & 97 & 168 & 72 & 43 & 2.8 & Accepted \\
\hline $\begin{array}{l}\text { Editorial helps me build more facts on } \\
\text { a given issue. }\end{array}$ & 233 & 64 & 29 & 54 & 3.3 & Accepted \\
\hline $\begin{array}{l}\text { Editorials help me form better } \\
\text { opinions on topical issues. }\end{array}$ & 159 & 91 & 76 & 84 & 2.7 & Accepted \\
\hline $\begin{array}{l}\text { Editorials help shape my world me. } \\
\text { Average Mean }\end{array}$ & 168 & 72 & 43 & 97 & 2.6 & Accepted \\
\hline
\end{tabular}

Source: Field survey, 2021 
Decision rule: Given that the benchmark of a 4-point Likert scale for decision is 2.5 , it means that

if the calculated mean is 2.5-4.0, then the item in question is accepted. However, if the calculated mean is 1-2.4, then the item in question is rejected.

The analysis of data in table 2 above revealed that at an average mean of 2.9 , newspaper readers in tertiary institutions were of the view that they were being influenced by the content of editorials that they read from newspapers. The implications of this finding is that editorials do help to mould the opinions of newspaper readers in tertiary institutions in Imo State.

Research Question Three: What are the factors that encourage the influence editorial has in moulding the opinions of newspaper readers in tertiary institutions in Imo State?

Table 3: Respondents views on the factors responsible for editorial's influence $(\mathrm{N}=380)$

\begin{tabular}{|l|l|l|l|l|l|l|}
\hline Option & SA & A & D & SD & Mean & Decision \\
\hline $\begin{array}{l}\text { Editorials are persuasively and } \\
\text { creatively written. }\end{array}$ & 200 & 88 & 84 & 27 & 3.2 & Accepted \\
\hline $\begin{array}{l}\text { The level of education of the readers } \\
\text { of editorials }\end{array}$ & 187 & 97 & 43 & 72 & 3.0 & Accepted \\
\hline $\begin{array}{l}\text { The newspaper outfit writing the } \\
\text { editorial. }\end{array}$ & 30 & 80 & 92 & 197 & 1.9 & Rejected \\
\hline Average Mean & & & & 2.7 & Accepted \\
\hline
\end{tabular}

Source: Field survey, 2021

Decision rule: Given that the benchmark of a 4-point Likert scale for decision is 2.5, it means that if the calculated mean is 2.5-4.0, then the item in question is accepted. However, if the calculated mean is 1-2.4, then the item in question is rejected.

Result of data communicated from table 3 above revealed that at an average mean of 2.7, newspaper readers in tertiary institutions in Imo State were of the view that the persuasive nature of editorials and the level of education of the person reading the editorials were the major factors responsible for the influence that editorial has in moulding peoples' opinions. The implication of this findings is that there are factors responsible for editorials influence in moulding peoples' opinions. 


\section{DISCUSSION OF FINDINGS}

The extent editorials are read by newspaper readers in tertiary institutions in Imo State

Analysis of data collected from the field revealed that 162 respondents representing $42.6 \%$ said that their readership of editorials in newspapers was to a very large extent. If this is added to the $36.3 \%$ of the people that said their readership of editorials was to a large extent, it will show that the the extent of readership of editorial was to a large extent as $78.9 \%$ of the readers were of that view.

The influence of editorials in moulding the opinions of newspaper readers in tertiary institutions in Imo State

Further analysis also revealed that at an average mean of 2.9, newspaper readers in tertiary institutions were of the view that they were being influenced by the content of editorials that they read from newspapers. The implications of this finding is that editorials do help to mould the opinions of newspaper readers in tertiary institutions in Imo State.

The factors that encourage the influence editorial has in moulding the opinions of newspaper readers in tertiary institutions in Imo State

Communicating result from data revealed that at an average mean of 2.7 , newspaper readers in tertiary institutions in Imo State were of the view that the persuasive nature of editorials and the level of education of the person reading the editorials were the major factors responsible for the influence that editorial has in moulding peoples' opinions. The implication of this findings is that there are factors responsible for editorials influence in moulding peoples' opinions.

\section{CONCLUSION}

Given that data analysis revealed that at an average mean of 2.9 , newspaper readers in tertiary institutions were of the view that they were being influenced by the content of editorials that they read from newspapers, it is therefore, safe to conclude that editorials do have influence in moulding the opinions of newspaper readers in the tertiary institutions. This conclusion is further supported by the finding on the factors responsible for the influence editorial has on peoples' opinion. The findings revealed that at an average mean of 2.7, newspaper readers in tertiary institutions in Imo State were of the view that the persuasive nature of editorials and the level of education of the person reading the editorials were the major factors responsible for the influence that editorial has in moulding peoples' opinions. 


\section{RECOMMENDATIONS}

The researcher recommended thus:

- Given that the the extent of readership of editorial was to a large extent as $78.9 \%$, it is recommended that newspaper readers should continue to read the editorial pages of newspapers while those that don't read editorial should be encourage to read.

- Considering that fact that at an average mean of 2.9 , newspaper readers in tertiary institutions were of the view that they were being influenced by the content of editorials that they read from newspapers, it is recommended that newspaper readers should continue to read editorials in order to form more informed opinions on topical issues

- Since an average mean of 2.7 newspaper readers in tertiary institutions in Imo State were of the view that the persuasive nature of editorials and the level of education of the person reading the editorials were the major factors responsible for the influence that editorial has in moulding peoples' opinions, it is recommended that newspapers houses should continue to creatively, persuasively and factually present the content of editorials in order for it to have more influence on peoples' opinions.

\section{REFERENCES}

Baker, D.C. \& Macdonald, J.C. (1961). Newspaper Editorial Readership and Length of Editorials. Retrieved from https://doi.org/10.1177/107769906103800404

Ciboh, R. (2014). Passive Accomplice or Active Acquiescent to Corruption in Nigeria? Evidence from Newspapers' Sourcing of Information on Corruption from 2000 - 2006. Studies in Media and Communication, 2(1), 115-124

D’Angelo, P. \& Shaw, D. (2018). Journalism as Framing. Handbooks of Communication Science, Vol. 19 (11), pp. 205-234. Retrieved from https://www.researchgate.net/publication/326249054_Journalism_as_Framing

Duyile, D. (2005). Writing for the media - A Manual for African Journalists. Lagos: Gong Communication.

Eaton, A. (2020). What Is "Media Framing" and Why Is It So Effective? Retrieved from https://medium.com/share-the-wealth/what-is-media-framing-and-why-is-it-soeffective-994ad8367381

Eilders, c. (2000). Media as Political Actors? Issue Focusing and Selective Emphasis in the German Quality Press. German Politics, 9 (3), 181 - 206

Elyazale, N. (2014). Characteristics of Newspaper Editorials: 'Chouftchouf in 'Almassae' Moroccan Newspaper as a Case Study. New Media and Mass Communication, 32, 21 43

Hoffman, M. (2007). Academic's Dictionary of Mass Communication. New Delhi: Academic.

Meltzer, K. (2007). Newspaper Editorial Boards and The Practice of Endorsing Candidates for political Office in the United State. Sage Journal. Retrieved from https://journals.sagepub.com/doi/10.1177/1464884907072422

Mughal (2014). Mass Media and Its influence on society. Retrieved from https://thedailyjournalist.com/pen-and-pad/mass-media-and-its-influence-on-society/

Okoro, N. and Agbo, B. (2003). Writing for the Media Society. Nsukka: Prize Publishers

Oluwakemi, O.M. (2016). News Analysis as a Media Content for Public Opinion Formation and Moulding. $\quad$ Retrieved from researchgate.net/publication/320487265_News_Analysis_as_a_Media_Content_for_ Public_Opinion_Formation_and_Moulding 
Orosa, G.B., García, L.X. and Santorum, G.S. (2013). Analysis of the Adaption of the Editorials of Five Newspapers from Different European Countries to the Online Environment. Revista Latina de Comunicatión Social. Retrieved from http://www.revistalatinacs.org/068/paper/986_USC/20_Orosaen.html

Richardson, J. (2007). Analysing Newspapers: An Approach from Critical Discourse Analysis. Retrieved from https://www.researchgate.net/publication/315685383_Analysing_Newspapers_An_a pproach_from_critical_discourse_analysis

Van Dijk, T. A. (1996). Opinions and Ideologies in Editorials. Paper for the 4th International Symposium of Critical Discourse Analysis, Language, Social Life and Critical Thought, Athens, 14-16 December, 1995. 